DEVELOPMENT OF MANAGEMENT

AND ENTREPRENEURSHIP METHODS ON TRANSPORT, № 1 (74), 2021
РОЗВИТОК МЕТОДІВ

УПРАВЛІННЯ ТА ГОСПОДАРЮВАННЯ

НА ТРАНСПОРТІ, № 1 (74), 2021
УДК 656.611.2

JEL Classification A 23, D 20, D 21, D 41

DOI 10.31375/2226-1915-2021-1-65-74

\section{ПРИНЦИПЫ ОПТИМИЗАЦИИ ЭКОНОМИЧЕСКОГО ПОЛОЖЕНИЯ СУДОХОДНОЙ КОМПАНИИ \\ В СИСТЕМЕ РЫНКА МОРСКОЙ ТОРГОВЛИ}

\author{
А.Ю. Стахов \\ аспирант кафедры \\ «Менеджмент и маркетинг» \\ forstudy@i.ua \\ ORCID 0000-0001-9739-6491
}

Одесский национальный

морской университет, Одесса, Украина

Аннотация. В основе устойчивости глобального рынка морской торговли лежат приоритеты международного разделения труда и конкурентного участия флота судовладельческих структур. Вместе с тем в условиях изменчивости темпов экономического роста мировой экономики возрастают риски устойчивости эффективного формирования производственного потенциала судоходных компаний. В этих условиях возрастает значимость своевременности принятия менеджерских и инновачионных решений по критериям адекватности предпринимательским иелям и принципам администрирования безопасности судоходства со стороны Международной морской организачии. Судовладельческие компании при развитии относительно ожидаемых грузопотоков должны переоченивать традициионную структуру рисков в связи с тем, что постоянно изменяются требования по безопасности судоходства. Это и усложняет оценку формирования необходимой инвестиционной программы.

Ключевые слова: торговое судоходство, оптимизачия, эффективность, капитальные активы, безопасность.
УДК 656.611.2

JEL Classification A 23, D 20, D 21, D 41

DOI 10.31375/2226-1915-2021-1-65-74

\section{ПРИНЦИПИ ОПТИМІЗАЦІї \\ ЕКОНОМІЧНОГО ПОЛОЖЕННЯ \\ СУДНОПЛАВНОЇ КОМПАНІЇ \\ У СИСТЕМІ РИНКУ МОРСЬКОЇ ТОРГОВЛІ}

\author{
A.Ю. Стахов \\ аспірант кафедри \\ «Менеджмент і маркетинг» \\ forstudy@i.ua \\ ORCID 0000-0001-9739-6491 \\ Одеський національний \\ морський університет, Одеса, Україна
}

Анотація. В основі стійкості глобального ринку морської торгівлі лежать пріоритети міжнародного поділу праці та конкурентного участі флоту судновласницькі структур. Разом з тим в умовах мінливості темпів економічного зростання світової економіки зростають ризики стійкості ефективного формування виробничого потенціалу судноплавних компаній. У ичих умовах зростає значимість своєчасності прийняття менеджерських та інновачійних рішень за критеріями адекватності підприємницьким ичілям $i$ принциипам адміністрування безпеки судноплавства з боку Міжнародної морської організації. Судновласницькі компанії при розвитку щзодо очікуваних вантажопотоків повинні переоцінювати традииійну структуру ризиків у зв'язку з тим, щзо постійно змінюються вимоги з безпеки судноплавства. Це $і$ ускладнює оцінку формування необхідної інвестииійної програми.

Ключові слова: торгове судноплавство, оптимізаиія, ефективність, капітальні активи, безпека.

(C) Стахов A.Ю., 2021 
UDC 656.611.2

JEL Classification A 23, D 20, D 21, D 41

DOI 10.31375/2226-1915-2021-1-65-74

\author{
Arsenii Stakhov \\ Graduate student (PHD) \\ of «Management and Marketing department» \\ forstudy@i.ua \\ ORCID 0000-0001-9739-6491
}

Odessa National Maritime University, Odessa, Ukraine

\title{
PRINCIPLES OF OPTIMIZING THE ECONOMIC SITUATION OF A SHIPPING COMPANY IN THE SYSTEM OF THE MARITIME TRADE MARKET
}

Abstract. The formation of the harmony of the maritime trade market is based on the reaction of ship-owning and port structures to the nature of changes in the main characteristics of cargo flows. At the same time, relations and the reaction of the ship-owning complexes to the optimization of the technical and economic level of the competitors are being formed. A shipping company as an enterprise develops and functions in contrast to other production structures of the national economy in the context of international competition. Regardless of the flag of registration of ships, companies operate in the global maritime trade market. It is the priorities of international conventions that determine managerial and marketing technologies. Therefore, a special nature of the participation of shipping companies in the formation of the final economic results is formed. It is this factor that requires constant clarification of the patterns of sustainable positionning in the system of the international division of labor. Also, it should be noted that the most important tendencies in improving the management of the development of subsystems of the national maritime transport industry are balancing the assessment of the merchant fleet and ports both from the standpoint of macroeconomic and entrepreneurial interests. Therefore, research focuses on the selection and implementation of the special priorities of the national maritime transport complex. In this regard, the temporal characteristics of the routes are considered rather thoroughly. However, the inconsistency of approaches to the formation of systemic security remains.

The efficiency of the state and functional and economic stability should be considered as the main criterion for changing the form of the ownership. With the stability and sustainability of maintaining the liquidity conditions of the enterprise, the change of ownership is determined by market conditions and the marketing strategy of the owner himself. Usually, in this state, the change in the form of ownership on the part of the owner has particular number of non-standard reasons. For such enterprises, privatization is problematic because it does not optimize the social and economic consequences and results.

Keywords: maritime trade, shipping companies, cargo flows, marketing technologies.

Постановка проблеми. Одним iз принципових положень функціональної діяльності підсистем націо- нальної морської транспортної індустрії є те, що після стабілізації виробничої і фінансової діяльності 
DEVELOPMENT OF MANAGEMENT

AND ENTREPRENEURSHIP METHODS ON TRANSPORT, № 1 (74), 2021
РОЗВИТОК МЕТОДІВ

УПРАВЛІННЯ ТА ГОСПОДАРЮВАННЯ

НА ТРАНСПОРТІ, № 1 (74), 2021 формується період різних структурних і кількісних змін. Інвестиційна діяльність у морській транспортній індустрії України протягом усього періоду практично не забезпечувала суттєвого оновлення виробничого потенціалу, за винятком розвитку ряду стивідорних компаній. Однак некерований кількісний ріст вантажопереробки не привів до зростання прибутку торгових портів і не став основою розвитку судноплавних компаній (СК) прапора України. Структурні зміни в вантажообігу, за рідкісним винятком (ТIC і «Південний»), не поліпшили фінансового становища торгових портів.

Протягом всього періоду розвитку України як морської держави не досягнуто збалансованого стану національної морської транспортної індустрії щодо параметрів участі країни в міжнародному поділі праці. Морська транспортна політика виявилася індиферентною щодо принципу фрахтової незалежності. У цих умовах і виникає потреба переглянути в сучасних умовах завдання розвитку морської транспортної індустрії та обліку найважливіших напрямків і закономірностей збалансованого позиціонування в глобальному ринку морської торгівлі.

Огляд останніх досліджень та літератури. Висока системна значущість підсистем морської транспортної індустрії зумовлює інтерес до розгляду характеру розвитку морського транспорту. Це підтверджує активність аналітичних і консалтингових структур таких, як UNCTAD, BRS, RS Platou i ін. [1;2]. У ряді відомих досліджень [3; 4] розглядаються системні підходи до формування підсистем глобального ринку морської торгівлі, представлені основні piшення і приватні питання [5; 6]. На жаль, внаслідок ігнорування ролі морського транспорту України з боку державної влади, не досягнуто стану повного відображення в науковометодичних матеріалах та постійно виникають нові проблеми.

Постановка задачі. Безперервні зміни ринку морської торгівлі істотно ускладнюють прийняття рішень щодо параметрів розвитку окремих судноплавних компаній $\mathrm{i}$ досягнення нормального економічного стану. Принциповим $є$ питання досягнення нормалізованого стану морської транспортної індустрії на основі підприємницьких пріоритетів прийняття інвестиційних i виробничих рішень окремими операторами [7].

Відповідно до зазначеного стає актуальним систематизація науковометодичних основ формування інвестиційної та ринкової позиції судновласницьких структур за критеріями ефективності щодо сукупності ризиків.

Основний матеріал дослідження. Будь-які поточні економічні проблеми вирішуються розробкою i реалізацією відповідних інвестиційних проектів і в меншій мірі організаційними та інституційними перетвореннями [8]. Саме через низькі темпи реалізації інвестиційних стратегій в основних галузях народного господарства посилювався розрив між рівнем конкурентоспроможності виробництва в Україні і в зарубіжних країнах.

Це необхідно враховувати при виборі стратегії досягнення адекватного стану підприємств морського транспорту щодо середніх параметрів 
сектора пріоритетної орієнтації судноплавного ринку. Системна обмеженість ресурсів зумовлює підвищення значущості диверсифікації [3]. Однак необхідно враховувати особливості роботи підприємств морського транспорту, що обмежує повне використання таких стратегій з урахуванням відомого положення: «Термін диверсифіковані фірми, ..., застосовується до компаній, які мають кілька дочірніх підприємств в інших галузях, але виробляють більшу частину продукції в рамках однієї промислової категоpiї» [8, с. 52]. 3 цієї позиції слід розглядати принцип порівнянності вит-рат в розвиток національних СК, портів, залізниці та автомобільного транспорту. Підвищення їх пропускної спроможності має грунтуватися на інвестиціях, що відображають місце торгового флоту і портів в транзитному потенціалі країни.

У стратегії розвитку найважливішим аспектом стає накопичення капіталу і виробничих інвестицій в проблемних підрозділах країни при дотриманні макроекономічних інтересів і підприємницьких економічних цілей. На цих засадах повинна бути уточнена політика державного регулювання економіки. До одних 3 найважливіших напрямків, реалізованих основними промислово розвиненими країнами, відноситься наступне.

По-перше, створення розвиненої системи нормативного регулювання охорони природи та праці, формування стандартів якості та безпеки виробничої діяльності.

По-друге, врахування ролі та значущості окремих секторів національної економіки в системі економічного зростання i добробуту, i зосередження уваги на цих галузях.
На жаль, структура експортних вантажопотоків 3 портів України свідчить про пріоритет сировинних ресурсів.

По-третє, активізація механізму конкуренції при певному зниженні регуляторних функцій держави, але при контролі поведінки монопольних структур.

По-четверте, використання принципів кастомізації при макроекономічному регулюванні попиту і пропозиції на основі кейнсіанської моделі розвитку. При цьому посилюється інституційний вплив на виробництво і пропозицію.

У будь-якому випадку при виборі параметрів спеціалізації транспортного підприємства необхідно враховувати те, що обробка і від-вантаження сировини і продукції розглядається як один з ключових елементів витрат в діяльності компанії, і ним необхідно управляти 3 метою мінімізації витрат [9, с. 432]. Це необхідно враховувати при виборі сектора позиціонування в сегментах фрахтового ринку нових судноплавних компаній (рис. 1). Крім того, цей принцип визначає оптимізацію технології трансшипменту щодо контейнерних сервісів.

Принципове значення займає оцінка ситуації в торговельному судноплавстві в розрахунковому періоді, тому що необхідно з найбільшою повнотою виявити нові стійкі тенденції, які зумовлюють завдання i обмеження інноваційного розвитку провізної здатності флоту. При цьому необхідно чітко визначити критерії вибору параметрів позиціонування в умовах, що склалися, формування конкурентного середовища в сегменті спеціалізації. 
DEVELOPMENT OF MANAGEMENT

AND ENTREPRENEURSHIP METHODS

ON TRANSPORT, № 1 (74), 2021
РОЗВИТОК МЕТОДІВ

УПРАВЛІННЯ ТА ГОСПОДАРЮВАННЯ

НА ТРАНСПОРТІ, № 1 (74), 2021

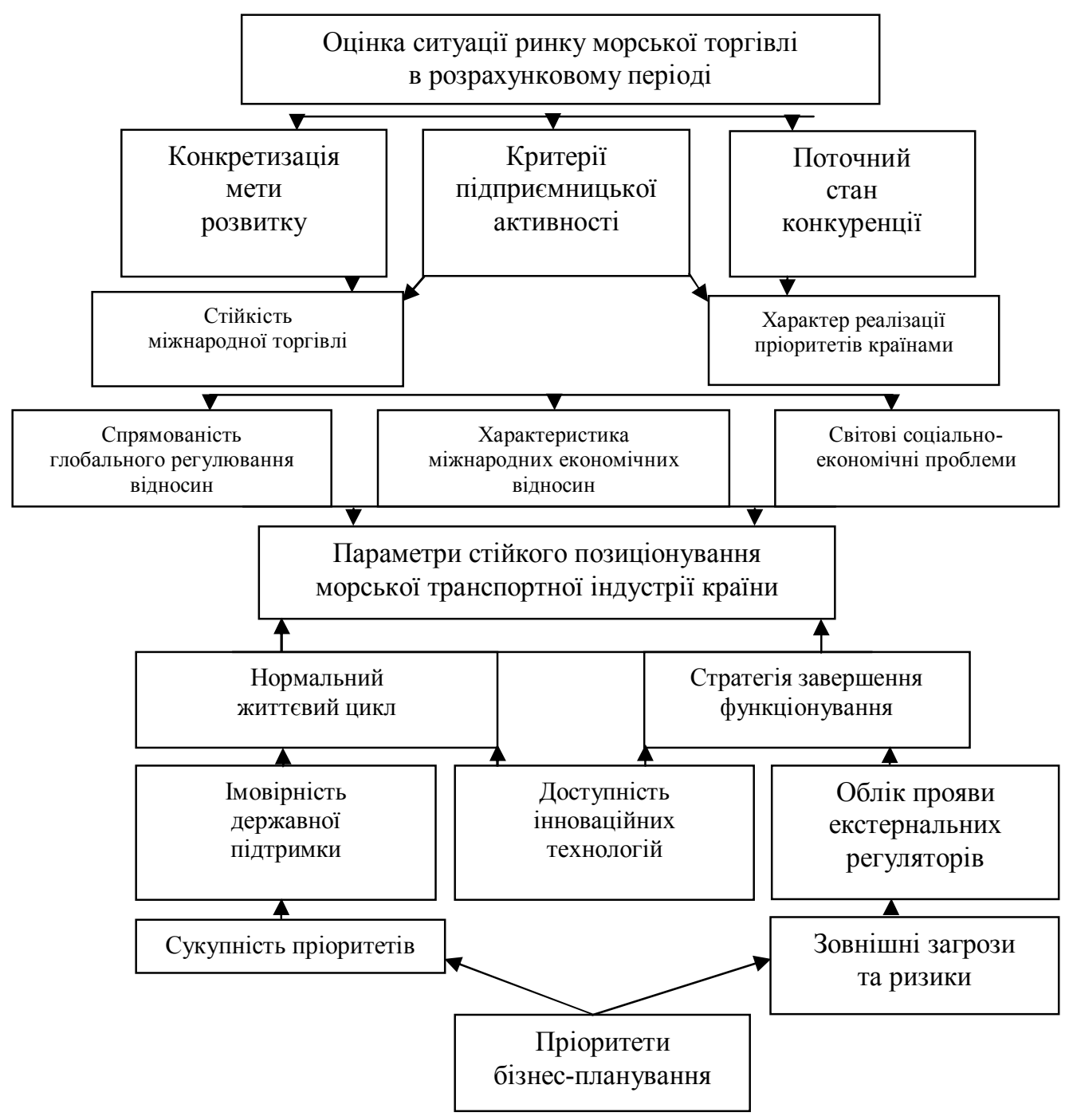

Рис. 1. Соціально-економічні характеристики

формування стратегії сталого позиціонування судновласників

\section{Джерело: власна розробка автора}

Видно, що параметри стійкого позиціонування національної підсистеми, що бере участь в глобальному ринку морської торгівлі, обумовлені складною сукупністю факторів. Виділяються як прямі економічні завдання, так і вплив зовнішніх регуляторів.
Центральною метою розвитку національної морської транспортної індустрії та окремих iï складових слід розглядати параметри стійкості за критеріями відповідності зовнішньоекономічних обмежень.

Фактично ця умова визначає постійну затребуваність інвестиційної 
DEVELOPMENT OF MANAGEMENT

AND ENTREPRENEURSHIP METHODS ON TRANSPORT, № 1 (74), 2021
РОЗВИТОК МЕТОДІВ

УПРАВЛІННЯ ТА ГОСПОДАРЮВАННЯ

НА ТРАНСПОРТІ, № 1 (74), 2021 активності, з одного боку, а, з іншого, внаслідок втрати інвестиційної привабливості національного флоту i портів формується втрата конкурентоспроможності та догляд в субстандартні позиції. Важливість морської транспортної індустрії для економічної незалежності країни вимагає активної підтримки з боку державних інститутів.

Цей процес заснований як на підприємницьких завданнях, так і на цілях макроекономіки, які реалізуються через відповідні міністерства. Наприклад, Міністерство транспорту (DOT) засновано Конгресом США в 1966 році з метою вирішення проблем безпеки, технології та розвитку масових перевезень. Федеральні ресурси розміщувалися за критеріями інтегрованої транспортної системи, яка націлена на вирішення істотних транспортних проблем.

Поряд 3 цим діяльність звичайних [9] перевізників США зовнішньої торгівлі по воді передбачає;

- регулювання діяльності національного перевізника при здійсненні перевезень всередині країни;

- здійснення контролю рівня ставок перевезень в межах прибережної зони країни.

В умовах жорсткої конкуренції і збоїв у механізмі «невидимої руки» формуються Федеральна комісія 3 морським перевезенням (FMC), що забезпечує транспортну діяльність із регулювання за критеріями системної результативності та ринкової збалансованості інтересів.

Подібним чином в системі ринкових відносин демонструються обставини справедливості, що випли- вають 3 твердження: «Часто єдиним прийнятним рецептом для бізнесу, в якому спостерігається спад, є обмеження інвестицій, досягнення максимальної ліквідності ...» [10, с. 137]. Ці умови і зумовлюють складність вибору стратегії позиціонування і управління антикризовими блоками менеджменту.

Серед проблем досягнення нормалізованого стану морської транспортної індустрії України в цьому аспекті виділяються:

- обмеженість відповідності економіко-правових аспектів розвитку національних підсистем морської транспортної індустрії щодо стандартів світової практики;

- відома обмеженість вільного доступу підприємств до інвестиційних джерел, що забезпечує можливість інноваційного розвитку;

- незбалансованість стану системи виробничого інфраструктурного комплексу країни щодо вимог конкурентного транзитного простору.

При формуванні концепції розвитку морського транспорту як способу розуміння завдань і параметрів становлення основних складових морегосподарського комплексу, як кон-структивного принципу виходу національного морського транспортного потенціалу на відкритий фрахтовий ринок необхідно розглядати нормалізовану [11] участь в розподілі фрахтових потоків в глобальному ринку морської торгівлі. Цим фактично зумовлюється техніко-економічний рівень національних судноплавних компаній і портів і їх конкурентоспроможність. 


$$
N_{p v i}=\sum \Delta Q_{i}\left[p_{c i}\left(1 \pm c_{c}\right)-\left(C_{s v a i}+\frac{C_{s a f i}}{\left(1+i_{q}\right)}\right)\right] \alpha_{t i}-\Delta K_{p i}
$$

де $\Delta Q_{i}-$ плановане розширення участі в сегменті глобального ринку морської торговлі за кількісними або конкурентними характеристиками, т;

$p_{c i}$-очікувана цінова характеристика в зоні операторської діяльності флоту компанії, дол / т;

$c_{c}$ - менеджерська оцінка можливого відхилення прийнятої тарифної ставки;

$$
C_{\text {svai }} \text { - величина середніх змін- }
$$

них витрат роботи флоту на напрямку, дол. / т;

$$
C_{\text {safi }} \text { - ставка постійних серед- }
$$

ніх витрат на напрямку для даного роду вантажу, дол. / т;

$$
i_{q} \text { - індекс зростання обсягу }
$$
перевезення вантажів;

$$
\alpha_{t i}-\text { коефіцієнт дисконтування }
$$
поточних економічних результатів по життєвому циклу, що відображає втрату вартості грошей у часі;

$$
\Delta K_{p i} \text { - необхідна величина }
$$

приросту капітальної вартості флоту.

Цей підхід, $з$ огляду на основні положення теорії ефективного зростання, відображає цільові завдання i умови досягнення стійкості в змінюваному ринку морської торгівлі. Інтуїтивне використання цього принципу в системі ринку морської торгівлі i зумовлює диференціацію техніко-економічного рівня флоту.

Відповідно до цього в межах реальної доступності і раціонального використання інвестиційних ресурсів програма розвитку морського транспорту повинна включати послідов- ність досягнення найважливіших показників, які забезпечують ефективний статус морської держави. Прийнятий інструментарій управління розвитком і діяльністю оператора повинен оптимізувати співвідношення підприємницької та макроекономічної складових морегосподарського комплексу.

Для опису економічних процесів і вирішення виникаючих питань щодо оптимізації позиціонування морських транспортних підприємств в межах сформованих умов найважливішим стає використання сучасної класифікаційної системи оціночних показників [3; 4]. Однак, класичний підхід виражений досить концептуально: «... 3 ростом ефективності, розмірів і вартості засобів виробництва ... праця зберігає і збільшує все в нових формах постійно наростаючу капітальну вартість» [12, с. 612]. Це підтверджується роботами, що розкривають роль ефективного використання інвестицій у виробничій сфері.

У цьому аспекті слід також погодитися 3 положенням, що карта цінності товарів і послуг формується відповідно до принципів диференціації ціни на нижчий, середній i вищий [12, с. 98]. Одночасно слід врахувати необхідність реалізації принципу єдності мети i завдань функціонування [13]. На жаль, незважаючи на єдність технологічного процесу транспортування вантажів, проблемою залишається роз'єднаність цілей інвестиційної політики та менеджменту в системі різних видів транспорту. 
DEVELOPMENT OF MANAGEMENT

AND ENTREPRENEURSHIP METHODS ON TRANSPORT, № 1 (74), 2021
РОЗВИТОК МЕТОДІВ

УПРАВЛІННЯ ТА ГОСПОДАРЮВАННЯ

НА ТРАНСПОРТІ, № 1 (74), 2021
Виникають непродуктивні простої. Ці додаткові витрати стримують грошовий потік, необхідний для реалізації інноваційних проектів інтеграції та розвитку єдиного інфраструктурного комплексу.

Незважаючи на прояв принципових положень ринкових відносин в торговельному судноплавстві, характер формування цінової характеристики певною мірою відрізняється від загальних положень [14]. Це зумовлюється незбалансованою активністю зростання пропозиції провізної здатності в трампових сегментах. Свобода операторської діяльності флоту різних реєстрів істотно знижує базову основу формування стійких фрахтових ставок.

Висновки. Закономірним залишається становище, що в основі формування принципів системної стійкості позиціонування судноплавних компаній лежать економічні закони. Ïх змістовний аспект формує вибір стратегії антикризового управління. При цьому слід враховувати особливості прояву основного змісту - сукупність методів використання принципів стійкості пріоритетів випередження за інноваційними технологіями [15]. Також варто відзначити, що найважливіше місце в управлінні повинно відводитися інструментарію прийняття i реалізації відповідних рішень.
Системні прорахунки в реалізації морської транспортної політики України, незважаючи на об'єктивну реальність, визначили значні втрати національної економіки. Лише пріоритети експорту сільськогосподарської продукції утримали інвестиційну привабливість торгових портів. Це зумовило розвиток окремих стивідорних комплексів на основі кредитного фінансування розвитку. Необгрунтованим слід вважати пріоритет передачі провідних портів в концесію. На жаль, ці проекти не забезпечили комплексність розвитку морської транспортної індустрії країни. Тому залишається актуальним питання формування та реалізації особливого підходу до вирішення проблеми транспортної безпеки участі резидентів країни в міжнародному поділі праці.

Представлений процес формування адекватної експлуатаційної діяльності флоту спеціалізованих судноплавних компаній зумовлює необхідність відображення критерію технічної та комерційної надійності, як основи не тільки утримання статусу, а й підвищення ефективності. Цим і зумовлюється місце навчально-методичних основ формування оптимального стану судноплавних компаній, що працюють в системі міжнародного ринку морської торгівлі і сполучень.

\section{СПИСОК ЛІТЕРАТУРИ}

1. Review of Maritime Transport. Report by the UNCTAD - New York and Geneve: UN, 2019. $160 \mathrm{p}$. 
2. Svitlana Filyppova, Valery Okulich-Kazarin, Olha Kibik, Grygoriy Shamborovskyi, Svitlana Cherkasova. Influence of the market of business intellectual services on the innovation safety of eu countries. JOURNAL OF SECURITY AND SUSTAINABILITY ISSUES / 2019 September Volume 9 Number 1. http://doi.org/10.9770/jssi.2019.9.1(26)

3. Примачев Н.Т. Принципы интеграиии в торговом судоходстве. Одесса: Феникс, Москва: ТрансЛит, 2006. 360 с.

4. Dykstra Don. L. Commercial Management in Shippin. London UK: Nautical Institute, 2005. $496 \mathrm{p}$.

5. Сенько О.В. Проблеми управління раціональністю національної підсистеми глобальної морської транспортної індустрії // Сочіально-економічний розвиток регіонів в контексті міжнародної інтеграиії. Херсон: 2018. № 28. C. 125-131.

6. Шевченко М. DHL обещает рост // Порты Украиныл. № 9 (171). 2017. C. 48-49.

7. Колегаєв І.М. Приниипи конкурентного розвитку спеціалізованого судноплавства глобальної морської індустрії. Одеса: НУ «ОМА», 2017. $332 \mathrm{c}$.

8. Гохан П.А. Слияния, поглощения и реструктуризащия компаний. Москва: Альпина Паблишер, 2018. 742 c

9. Линдерс М.Р., Харольд Е.Ф. Управление снабжением и запасами. Логистика; пер. с англ. М.: Полигон, 1999. 768 c.

10. Портер М. Конкурениия. М.: Изд. Дом «Вильямс», 2008. 602 с.

11. Дамодаран А. Инвестиционная оиенка: Инструменты и техника оиенки любых активов; пер. с англ. М.: Альпина Бизнес Букс, 2004. 1342 с.

12. Долан Р. Дж., Саймон Г. Эффективное иенообразование. М. Экзамен, 2005. $416 \mathrm{c}$.

13. Звсряков М. I. Національна економічна система: проблеми теорії. Одеса: Acтропринт,2012. 513 c.

14. Onyshchenko, S.P., Koskina, Yu.O. (2015). Research of the effect of terms and conditions of an offer on successful conclusion of the freight transaction. Eastern-European Journal of Enterprise Technologies, 6 (3(78)). 25-32. DOI: 10.15587/1729-4061.2015.55738 http://journals.uran.ualeejet/ article/ view/85233

15. Izabela Kotowska, Marta Mańkowska and Michat Pluciński. Inland Shipping to Serve the Hinterland: The Challenge for Seaport Authorities, 2018. MDPI, Open Access Journal, vol. 10(10), pages 1-17. URL: https://www.mdpi.com/ 2071-1050/10/10/3468. DOI: 10.3390/su10103468

\section{REFERENCES}

1. Review of Maritime Transport. Report by the UNCTAD. - New York and Geneve: UN, 2019. $160 \mathrm{p}$. 
2. Svitlana Filyppova, Valery Okulich-Kazarin, Olha Kibik, Grygoriy Shamborovskyi \& Svitlana Cherkasova (2019). Influence of the market of business intellectual services on the innovation safety of eu countries. JOURNAL OF SECURITY AND SUSTAINABILITY ISSUES. Volume 9. Number 1. http://doi.org/10.9770/jssi.2019.9.1(26)

3. Prymachov, N.T. (2006). Pryntsypy intehratsiyi $v$ torhovelne sudnoplavstvo [Integration principles in merchant shipping]. Odesa: Feniks, Moskva: TransLyt, 360 [in Russian].

4. Dykstra Don. L. (2005). Commercial Management in Shipping. London UK: Nautical Institute, $496 \mathrm{p}$.

5. Sen'ko O.V. (2018). Problemy upravlinnya ratsional'nistyu natsyonal'noy pidsistemi hlobal'noyi mors'koyi transportnoyi yndustryy [Problems of Rationality Management of the National PidSystem of the Global Maritime Transport Industry]. Sotsial'no-ekonomichnyy rozvytok rehioniv $v$ konteksti mizhnarodnoyi intehratsiyi - Social and economic development of regions in the context of international integration]. Kherson. № 28. 125-131 [in Ukrainian].

6. Shevchenko, M. (2017). DHL obitsyaye zrostannya [DHL promises growth]. Porty Ukrayiny [ports of Ukraine]. № 9 (171). 48-49 [in Ukrainian].

7. Kolehayev, I.M. (2017). Pryntsypy konkurentnoho rozvytku spetsializovanoho sudnoplavstva hlobal'noyi mors'koyi yndustryy [Principles of competitive development of special shipbuilding of the global marine industry]. Odesa: NU «OMA», 332. [in Ukrainian].

8. Hokhan, P.A. Zlyttya, pohlynannya ta restrukturyzatsiya kompaniy [Mergers, acquisitions and company restructuring]. Moskva: Alpina Pablisher [in Ukrainian].

9. Linders, M.R. \& Kharol'd, E.F. (1999). Upravlinnya postachannyam $i$ zapasamy. Lohistyka [Supply and inventory management. Logistics]. M.: Polihon, 768 [in Ukrainian].

10. Porter, M. (2008). Konkurentsiya. [Competition] M.: Yzd. Budynok «Vil'yams», 602 [in Russian].

11. Damodaran, A. (2004). Investytsiyna otsinka: Instrumenty i tekhnika otsinky bud'-yakykh aktyviv [Investment Appraisal: Tools and Techniques for Appraising Any Assets]; per. $z$ anhl. M.: Al'pina Biznes Buks, 1342 [in Ukrainian].

12. Dolan R.Dzh. \& Saymon H. (2005). Efektyvne tsinoutvorennya [The effective pricing]. M.: Ispyt, 416 [in Ukrainian].

13. Zvryakov, M.I. (2012). National economic system: problems of theory. Odesa: Astroprint, 513 [in Ukrainian]

14. Onyshchenko, S.P. \& Koskina, Yu.O. (2015). Research of the effect of terms and conditions of an offer on a successful conclusion of the freight transaction. Eastern-European Journal of Enterprise Technologies, 6 (3 (78)), 25-32. DOI: 10.15587 / 1729-4061.2015.55738. Retrieved from http:// journals. uran.ua/ eejet/article/view/85233. 
15. Izabela Kotowska, Marta Mańkowska and Michat Pluciński. Inland Shipping to Serve the Hinterland: The Challenge for Seaport Authorities, 2018. MDPI, Open Access Journal. Vol. 10(10). P. 1-17. Retrieved from https://www. mdpi.com/2071-1050/10/10/3468. DOI: 10.3390/su10103468

Стаття надійшла до редакиії 11.02.2021

Посилання на статтю: Стахов А.Ю. Принципи оптимізації економічного положення судноплавної компанії у системі ринку морський торгівлі // Розвиток методів управління та господарювання на транспорті: Зб. наук. праць, 2021. № 1 (74). С. 65-74. DOI 10.31375/2226-1915-2021-1-65-74.

Article received 11.02.2021

Reference a JournalArtic: Stakhov, Arsenii. (2021). Principles of optimizing the economic situation of a shipping company in the system of the maritime trade market. Development of management and entrepreneurship methods on transport. 1 (74), 65-74. DOI 10.31375/2226-1915-2021-1-65-74. 